УДК 35.071.6:316.422(477)(474.3)-021.272»1991/2021" DOI https://doi.org/10.31470/2518-7600-2021-12-69-88

PECULIARITIES AND PROBLEMS OF REFORMING LOCAL SELF-GOVERNMENT AND TERRITORIAL STRUCTURE OF POWER IN UKRAINE AND LATVIA IN 1991-2021

\title{
ОСОБЛИВОСТІ І ПРОБЛЕМИ РЕФОРМУВАННЯ МІСЦЕВОГО САМОВРЯДУВАННЯ ТА ТЕРИТОРІАЛЬНОЇ ОРГАНІЗАЦЇ̈ ВЛАДИ В УКРАЇНІ ТА ЛАТВІї У 1991-2021 РОКАХ
}

\section{ОСОБЕННОСТИ И ПРОБЛЕМІ РЕФОРМИРОВАНИЯ МЕСТНОГО САМОУПРАВЛЕНИЯ И ТЕРИТОРИАЛЬНОЙ ОРГАНИЗАЦИИ ВЛАСТИ В УКРАИНЕ И ЛАТВИИ В 1991-2021 ГОДАХ}

\section{Неоніла Красножон,}

кандидат історичних наук, доиент кафедри загальної історії, правознавства $i$ методик навчання Neonila.krasnozhon@gmail.com https://orcid.org/0000-00034735-0641

Університет Григорія Сковороди в Переяславі, м. Переяслав, вул. Сухомлинського, 30 , Київська обл., Україна, 08401
Neonila Krasnozhon, Ph.D. in Historical Sciences, Assistant Professor of Department of General History, Science of Law and Teaching Methods

Neonila.krasnozhon@gmail. com https://orcid.org/0000-00034735-0641

Hryhoriy Skovoroda University in Pereyaslav, Pereyaslav, 30, Sukhomlynskoho Str., Kyiv region, Ukraine, 08401

\section{АНОТАЦІЯ}

Стаття висвітлює особливості реформ децентралізації в Украӥні та Латвї, втілення їх у життя та аспекти, які $\epsilon$ 
визначальними в реалізачії їх успішного проведення: на латвійському прикладі для України.

У публікації визначено, щзо в Україні децентралізачія розпочалась, як $i$ в Латвї, із низового адміністративнотериторіального рівня та є глобальною перебудовою моделі управління в державі, створення ефективной системи територіальної організаціі влади відповідно до положень Свропейської хартії місчевого самоврядування, але відсутній дієвий механізм, який би забезпечив практичну реалізацію права громади на прямі практичні дї реалізачії ряду поточних питань громади. А децентралізаџї в Латвї, так само, як $і$ в Україні, усі роки розбудови відновленої незалежності, включала декілька окремих реформ, які проходили не синхронно, через щзо виникало багато труднощуів $i$ проблем. Так, бюджетна децентралізація передувала реформам рад та адмінустрою. Реформа місцевого самоврядування розпочалася раніше і саме самоврядуванню закон дав більше повноважень, але громади не могли реалізувати изі повноваження, бо були неукрупнені, невеличкі за розмірами $i$ недостатньо спроможними діяти самостійно.

У статті визначено ряд рекомендачій, які вартують їx дотримання при подальшій реформі децентралізації в Україні: не відкладати заходи по введенню фінансової $i$ адміністративної автономіі, інакше буде більще супротиву, чим підтримки; сприяти не лише об'єднанням, але паралельно розвивати і співробітництво; по мірі можливостей сприяти створенню $i$ укріпленню єдиної асоціації самоуправлінь, проводячи із нею консультацї при кожному кроці реформ4; консультуватися із кожним самоуправлінням і компенсовувати та допомагати тим, хто може опинитись на околиці; децентралізовувати окремі функиії разом із реформами.

В дослідженні зроблені висновки, щуо долаючи довгий илях реформ в умовах нестабільності політичної і економічної, ефективність децентралізації в Україні залежить від того, наскільки спроможними стануть громади, які об'єднались $i$ 
наскільки дієвим інструментом із наданню послуг населенню вони будуть. Формування громад в Україні сьогодні відбувається в умовах світової пандемії, складних геополітичних трансформацій, економічної кризи і потребує як подальших досліджень проблеми, вивчення зарубіжного досвіду, так $i$ зусиль всіх, без винятку: $i$ законодавия, $i$ керівників громад, $i$ обраних, делегованих від народу представників ОТГ, і від кожного пересічного громадянина. Тільки згуртована командна робота, спрямована на позитивний, чітко визначений у стратегічних иілях громади, результат; сумлінна сплата податків; прозорий розподіл та вдала реалізація $i$ освоєння коштів; життєздатна інвестиційна політика, - зможуть гарантувати бажаний позитивний результат і комфортне життя для населення $в$ об 'єднаній територіальній громаді.

Ключові слова: деценттралізація, Украӥна, Латвія, реформи, місиеве самоврядування, влада, обєднані територіальні громади.

The relevance of the research is determined by the irrefutable argument of all democratic societies stating that the farther is the management the more collective action it takes to secure changes, the more difficult it is to control and influence the authority, and the easier it is for officials and politicians to conceal corruption. With civil control at the level of local communities, it does not matter what particular party is currently in power. These substantial reasons make it necessary for countries with sustainable economy (the group to which Latvia and Ukraine currently gravitate towards) to launch decentralization reforms which are based on, and implement the following basic principles: grass-root local selfgovernment has a significant executive and budgetary independence; local communities receive a share of taxes imposed on economic activities of physical persons and legal entities registered in their territory (hence they provide all kinds of support to encourage businesses and attract investments); there is a clear- 
cut division of powers and resources between the state and regional/local authorities. These are the fundamental positions that make peculiarities of Latvia's decentralization reform interesting for our analysis, with subsequent adoption of this experience for Ukraine, which strengthens the relevance of our research.

Analysis of recent research on the topic indicates that modern research works dedicated to problems of decentralization and topics of implementing local self-government reform in Ukraine, issues related to discharge of inherent and delegated powers by local self-government bodies, their cooperation with public authorities, and problems of legislative support for decentralization reforms clearly demonstrate the interest of academic community in this field (Бабюк, Чепель; Матвієнко, 2011; Скрипнюк, 2015; Chepel, 2015; Цурканова, 2014). Some problems of Latvia's decentralization reforms have also been interpreted scientifically by specialists in various fields of knowledge (Ткачук, 2015; History and progress, 2009; Mapic Пукіс). However, this topic lacks a generalizing historical and comparative study on peculiarities in performance of decentralization reforms in Ukraine and Latvia, and the consequences of these reforms for the population.

The purpose of this scientific study is to determine peculiarities of decentralization processes in Ukraine and Latvia, while looking for opportunities to use the Latvian experience for development of local self-government in Ukraine.

Results of the research. Decentralization is one of the forms in which democracy is evolving; it allows to expand local selfgovernment, preserve the unity of the state and its institutions, stimulate people's activity for satisfaction of their own interests and needs, reduce the field of state influence on the society by replacing this influence with self-regulation mechanisms created by the society itself, and reduce the cost of maintenance of the state machinery for the state itself and its taxpayers (Скрипнюк, 2015: 23). The local self-government reform envisages transferring a share of national taxes to local budgets, encourages the economic interest 
of communities to develop new production facilities and attract investments thus facilitating the overall economic development of the country, and it also strives to change the people's awareness of the concept and process of decentralization.

Just as in Latvia, the decentralization process in Ukraine began from the grass-root administrative-territorial level and strives for a global transformation of the country's administration model, and creation of an effective territorial structure of power in accordance with the provisions of the European Charter of Local Self-Government. The experience of such countries as Denmark, Norway, Sweden, Poland, Czech Republic, Estonia, France shows that delegation of significant powers from public authorities to local self-government bodies (in particular, with the grass-root bodies having as much power as possible) ensured strengthening of local self-government and therefore removed artificial obstacles (unnecessary permits, excessive control of the central government, encumbrance of bureaucracy) for business and entrepreneurial activities, creation of a transparent investment climate and enabled capable communities (in terms of money and resources) to solve local issues more efficiently for the benefit of their population and development of their territories (Бабюк, Чепель).

In terms of legal regulation and provisions for decentralization in Ukraine, the process began in 2014 with approval of the Concept of Reforming Local Self-Government and Territorial Structure of Power (01.04.2014) (Концепція реформування..., 2014). То facilitate its realization and ensure performance of the Action Plan for implementation of the reform of local self-government in Ukraine, amendments were introduced into the Budget Code and Tax Code of Ukraine along with adoption of the Law of Ukraine «On Cooperation of Territorial Communities» dated 17.06.2014 that encouraged communities to unite and cooperate, and strived to improve their capability through the mechanism of establishing direct inter-budget relations between community budgets and the state budget. On 5 February 2015, the Verkhovna Rada of Ukraine passed the Law of Ukraine "On Voluntary Amalgamation of 
Territorial Communities" No. 157-VIII (hereinafter Law 157) (3У «Про добровільне об'єднання територіальних громад», 2015) which regulates relations emerging in the course of voluntary amalgamation of territorial communities of villages, townships and cities. To ensure implementation of the Law of Ukraine «On Voluntary Amalgamation of Territorial Communities» the Cabinet of Ministers of Ukraine approved the Resolution «On Methodology of Formation of Capable Territorial Communities» No.214 dated 08.04.2015 (hereinafter the Methodology) (Методика формування спроможних територіальних громад, 2015). On 17 November 2020, the Verkhovna Rada of Ukraine passed the Law «On introduction of amendments to certain laws of Ukraine as regards adjustment of specific issues in organization and activity of local

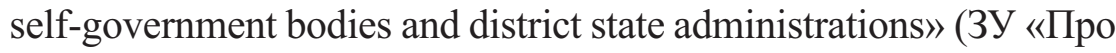
внесення змін до деяких законів України...»). These were the enactments that determined the mechanism and principles for amalgamation of communities as capable entities that are able, independently or through corresponding local self-government bodies, to ensure proper quality of services provided, in particular, in the field of education, culture, health care, social protection, urban development, housing services and utilities with consideration of staff resources, financial support and infrastructural development in corresponding administrative-territorial units (Chepel, 2015:39). Therefore, the state envisages that within capable territorial communities of Ukraine, local self-government bodies will be able to realize their inherent powers as well as the powers delegated by the state in terms of providing services to the population of their village, township or city.

It is at the local level where people have the opportunity to directly influence the process of decision-making to improve their lives that theoretical basis of democracy finds its practical meaning, and this gives a substantial boost for development of democratic processes in the society (Цурканова, 2014:276).

However, the problem is that Ukraine lacks legal arrangements to ensure implementation of the people's right to 
direct practical action for solving current issues of their local community.

The Republic of Latvia, a country with a small and underpopulated territory, with some tourist attractions and authentic, interesting history faced an imbalance in development of its regions after the breakup of the Soviet Union and declaration of its independence on 4 May 1990. That is why, similarly to Ukraine, the process of decentralization in Latvia over the several decades of its restored independence included several stages of reforms that did not always run synchronously and caused a great deal of difficulties and problems. For instance, budget decentralization preceded the reforms of local councils and administrative structure. Reforms of local self-government began earlier, and the law gave more powers to local governments, but communities could not implement them as they were non-consolidated, small in size, and had little capability for independent activities.

The administrative-territorial reform lasted for 11 years (1998-2009) and encountered great difficulties, but it brought very important results. Just as in Ukraine, the first stage was that of voluntary amalgamation, and the picture was quite pessimistic as two thirds of local government leaders (before the reform, there were 590 local governments) were totally opposed to any reforms, to say nothing of the people at large. As a result, only 20 amalgamated communities appeared in the first six years of the voluntary stage. There were also attempts to develop cooperation between communities, and they were equally unsuccessful. Still, the government promoted progress in this field with the help of ample infrastructure subsidies, and 110 amalgamated communities, known as novadi (municipalities) in Latvia, were formed in 2009. With all that, 35 local governments remained non-consolidated until 2009 in spite of the subsidy incitements, and these were turned into amalgamated communities on a compulsory basis and without any subsidies offered. They were offended by the refusal and sued the government, but the Constitutional Court admitted their defeat. The government did not stop and suggested further territorial reforms 
that are currently underway and envisage consolidation of basic administrative units.

Back in the early 1990s, Latvia saw discussions on reformation of its administrative-territorial arrangement. At that time, the Republic of Latvia consisted of 590 local governments: 26 districts, 7 republican cities, 17 amalgamated local municipalities, 475 parishes, and 58 towns. Within the first five years of the reform, a series of laws on local self-government were adopted, and a concept for reforming the local governments (legal, financial, administrative-territorial) was approved (Ткачук, 2015:7$8)$. At the same time, the reform of local self-government was seen as a component of reforming the public administration system.

In Latvia, financial decentralization started in 1995-1998, with adoption of laws «On Budgets of Local Governments» and «On Financial Levelling of Resources of Local Governments» that suggested 15 self-governed entities should pay into the fund, and the others receive funding from there.

In 1998, the law «On Administrative-Territorial Reform» was adopted (Матвієнко, 2011:675) that envisaged formation of administrative territories with local and regional self-government bodies that could be able to develop their economies, ensure provision of quality services to the people, and build up their human resources. This reform was driven and dictated by the country's goals of European integration and accession to the EU.

Certain apprehensions of Latvia's political elite concerning implementation of a comprehensive and all-round reform to forcibly change the territorial arrangements were reflected in the procedural mechanism of "voluntary amalgamation of parishes" that created only 20 self-governed entities in 6 years, and can be explained by the negative attitude of the people to such changes. Experts tend to believe that a considerable percentage of negative and neutral responses can be put down to lack of information and proper explanations on the part of public authorities about the essence of the reform and its consequences. Another serious obstacle was uncertainty about the course of the process. Recognizing the lack 
of strong political will to implement the reform, local authorities preferred to delay its implementation (Матвієнко, 2011:679).

In parallel, they developed cooperation between local governments, hoping that cooperation can replace amalgamation. In fact, it never happened: 5 or 6 cooperation groups had been created but they broke up after a few years because cooperation did not work as expected. One convocation of people's deputies decided to enter cooperation agreements, and after elections, the new convocation would decide to stop cooperation. Most of the smaller parishes did not intend to be consolidated in spite of the government's support for such amalgamation. Problems with voluntary amalgamation began to arise. Heads of parishes who negotiated amalgamation were hardly willing to considering interests of the neighbouring parishes and the governmental intention to open new capabilities for the united parishes.

In the early 2001, the Project of administrative division of local self-government based on the study of administrative territories, the experience of reforms and recommendations of international experts presented a set of common national criteria to form new territories along with proposals regarding the administrative division of the country's territory into 102 local selfgovernment bodies (Матвіснко, 2011:677). The central government was more interested in forcible amalgamation than in encouraging cooperation between local authorities because it would reduce the number of administrative units. Although the central government supported amalgamation of municipalities by administrative methods, local leaders preferred voluntary amalgamation. At the end of 2007, about 70 self-governed entities expressed their dissatisfaction with the current model, and it resulted in creation of another 7 amalgamated municipalities on the basis of appeals from 20 local self-government bodies (History and progress..., 2009:21).

In 2009, the original group of 500 local governments was transformed into a smaller set of 110 (currently known as municipalities). After the amalgamation, the state provided an additional subsidy in the amount of 5\% from the total budget of the 
amalgamated community. Every amalgamation created under the project received a one-time subsidy of 285,000 euro which was usually invested into the municipality's infrastructure. In 2009, 35 local governments were united forcibly and without subsidies. Some parishes that were unwilling to unite went to the Constitutional Court, claiming that the amalgamation under the government's decision was illegal. However, Latvia's Parliament made changes to the legislation to enable the Government to determine the boundaries of self-governed entities, and it was decided that the Parliament had to approve of all local governments created in the course of the reform. Within one day, the Parliament applied the law to confirm creation of all local governments (Ткачук, 2015:20).

As to decentralization in Ukraine, 159 communities were united following the results of local elections that took place on 25.10 .2015 , about $30 \%$ of them being recognized as capable. The other $70 \%$ required subsidies but nevertheless the government recognized them to be capable which allowed to ensure direct interbudget relations between the central government and amalgamated communities in terms of the latter's performance of delegated powers in the field of education, health care, social protection etc. As of 2016, the state allocated UAH 1 bln in subsidies for infrastructure; amalgamated communities started by using UAH 120,000 of this amount, and then finally managed to use $95 \%$ of the subsidy (Об'єднані громади освоїли...). In 2016, 209 communities also united on a voluntary basis, and this number could even be higher but the Central Election Commission could not find legal grounds to set elections in 28 amalgamated communities. In this group, 25 communities included local councils from several districts or had a regional town as their centre. As of January 2017, 367 communities were united in Ukraine (ОТГ: оприлюднено Карту...), which accounted approximately for $17 \%$ of amalgamated territorial communities. As of 2017, the state allocated total subsidies of UAH $1.5 \mathrm{bln}$ for development of infrastructure in amalgamated territorial communities (including UAH 0.5 bln from stable sources), but local budgets were additionally bound with the 
obligation to pay utility expenses and other costs in the field of education and health care (АМУ заявляє про зниження...).

Despite great difficulties, the Ukrainian decentralization reform continues. After 6 years of the reform, Ukraine created 1,070 amalgamated territorial communities which united 4,882 communities on a voluntary basis. Out of this number, 936 communities have already had their first local elections. The total area of the existing amalgamated communities makes almost $47 \%$ of Ukraine's territory. Amalgamated territorial communities and cities of regional subordinance account for over $70 \%$ of Ukraine's population (ЗУ «Про внесення змін...»). Unfortunately, quantity does not reflect quality. For example, in Ukraine the state delegates its powers in the field of education and health care to amalgamated communities, but contrary to Paragraph 5 of the Concept of Reforming Local Self-Government, it reduces the volume of subsidies for the delegated powers. Meanwhile, in Latvia financial stability for amalgamated communities is guaranteed and ensured at all levels that belong to the functions of Latvia's local selfgovernment: water supply and heating, waste collection and utilization, public services and infrastructure, public management of forest and water resources, primary and secondary education, culture, health care, social protection, child welfare, social housing, licensing for commercial activities, law enforcement and civil protection, urban development, collection of statistical data, public transport, and teacher training.

The latest proposals regarding Latvia's decentralization reform currently discussed in the academic and political circles suggest consolidating the existing communities and have 36 units instead of the current 119, which would become the European Union's largest local governments (2 cities and 34 municipalities), and the next step should be the review of functions and finance of the self-governed bodies, after the 2021 elections. There are alternative ideas that suggest new approaches to regional development through formation of self-governed entities (districts) and review of criteria for local self-government. Also, Latvia 
promotes development of cooperation networks that help local governments to share their experience, look for innovative solutions for every specific case, and find practical application for various ways of cooperation to solve issues that cannot be handled by a single local government body.

The Latvian Association of Local and Regional Authorities led by Maris Pukis (senior adviser, Ph.D. in Economics) has developed a set of recommendations for countries that work towards decentralization, and we believe that these guidelines should be observed in the further course of Ukrainian decentralization reform:

1. Do not postpone activities that introduce financial and administrative autonomy: otherwise, there will be more resistance than support.

2. Promote amalgamation, but develop cooperation at the same time.

3. If and when possible, encourage creation and strengthening of a united association of local governments, and consult with it at every stage of reforms.

4. Consult with every local authority, compensate and help those who may find themselves on the margin.

5. Decentralize separate functions along with the reforms (Пукіс, 2019).

Conclusions. Therefore, proceeding on a long way of reformation in the conditions of economic and political instability, effectiveness of decentralization in Ukraine depends on how capable the united communities can become and how efficient they can be in providing all the necessary services to the people. These days, communities in Ukraine are formed in conditions of the global pandemic, complicated geopolitical transformations, and an economic crisis, and this process requires further research in this field, a thorough study of international experience just as much as it requires certain efforts from virtually everyone: legislators, community leaders, people's elected representatives in communities, and each member of such community. Only a 
combination of teamwork meant to achieve a positive result of meeting the strategic goals of community, diligent payment of taxes, transparent distribution and successful allocation/use of funding, and a sound investment policy can guarantee the desired result and comfortable living for the people of an amalgamated territorial community.

\section{ДЖЕРЕЛА ТА ЛІТЕРАТУРА}

1. АМУ заявляє про зниження фінансової спроможності місцевого самоврядування у 2017 p. URL: http: www.auc.org.ua/novyna/aти. ișpi]

2. Бабюк I., Чепель О. Основні аспекти формування спроможних територіальних громад. URL: http://www.bukvisnyk.cv.ua.

3. Закон України «Про добровільне об'єднання територіальних громад» від 05.02.2015 р. № 157-VIII. Відомості Верховної Ради Украӥни. 2015. № 13. Ст. 91.

4. Закон України «Про місцеве самоврядування в Україні» від 21.05.1997. № 280/97. Відомості Верховної Ради України. 1997. № 24. Ст. 170.

5. Концепція реформування місцевого самоврядування та територіальної організації влади в Україні затверджена розпорядженням Кабінету Міністрів України від 01.04.2014 p. № 333-p. Офіиійний вісник Украӥни. 2014. № 30. Ст. 831.

6. Матвієнко А. Реформа адміністративно-територіального устрою в Латвії. Держава і право. 2011. Вип. 54. С. 674-680.

7. Методика формування спроможних територіальних громад, затверджена Постановою Кабінету Міністрів України від 08.04.2015 р. № 214. Офіційний вісник Украӥни. 2015. № 33. Ст. 963.

8. Скрипнюк О. Децентралізація влади як чинник забезпечення стабільності конституційного ладу: теорія й практика. Віче: громадсько-політичний і теоретичний журнал. 2015. № 12. C. 22-24. 
9. Ткачук А. Латвія: довга дорога реформи. Робочі записки. Київ: К.І.С., 2015. 56 с.

10. Об’єднані громади освоїли 95\% субвенції на розвиток інфраструктури своїх територій. Реформа діє! URL: http: http://www.minregion.gov.ua.

11. History and progress of administrative-territorial reform in Latvia. - Riga, Ministry of Regional Development and Local Government of the Republic of Latvia, 2009. 27 p.

12. Chepel 0. Combining of local communities in measures of decentralization in Ukraine. EUROPEAN JOURNAL - of - LAW and PUBLIC ADMINISTRATION / Olga Chepel/ Ştefan cel Mare University from Suceava Faculty of Economics and Public Administration Department of Law and Public Administration. Lumen, 2015. Vol. 2. Issue 3. P. 37-43.

13. Цурканова И. Демократический политический процесс как фактор структурных изменений в системе исполнительной власти в современной Украине. Філософія $i$ політологія в контексті сучасної культури. 2014. Вип. 8. С. 273-276.

14. ОТГ: оприлюднено Карту процесу формування об’єднаних громад в Україні. URL: http://decentralization.gov.ua/ news.

15. Эдвинс Ванагс, Инга Винкс Местное самоуправление в Латвии. URL: https://cutt.ly/UQXDd3S

16. Закон «Про внесення змін до деяких законів України щодо впорядкування окремих питань організації та діяльності органів місцевого самоврядування i районних державних адміністрацій. URL: https://cutt.ly/nQXDgmA

17. Реформа децентралізації. Урядовий портал URL: https://cutt.ly/sQXDjW0

18. Маріс Пукіс. Адміністративно-територіальна реформа в Латвіï.https://cutt.ly/8QXDxUg

\section{REFERENCES}

1. AMU zayavaliaye pro znyzhennia finansovoi spromozhnosti mistsevogo samovriaduvannia u 2017 r. [The Association of 
Ukrainian Cities reports decreasing financial sufficiency of local self-government in 2017]. Retrieved from http: www.auc.org.ua/novyna/ати [in Ukrainian].

2. Babiuk, I. \& Chepel, O. Osnovni aspekty formuvannia spromozhnykh terytorialnykh hromad [Main aspects in formation of capable territorial communities]. Retrieved from http://www.bukvisnyk.cv.ua [in Ukrainian].

3. Zakon Ukrainy «Pro dobrovilne obiednannia terytorialnykh hromad» [The Law of Ukraine «On Voluntary Amalgamation of Territorial Communities» No.157-VIII dated 05.02.2015]. (2015). Vidomosti Verkhovnoi Rady Ukrainy - Bulletin of the Verkhovna Rada of Ukraine, 13, 91 [in Ukrainian].

4. Zakon Ukrainy "Pro mistseve samovriaduvannia v Ukraini»" [The Law of Ukraine "On Local Self-Government in Ukraine" No. 280/97 dated 21.05.1997]. (1997) Vidomosti Verkhovnoi Rady Ukrainy - Bulletin of the Verkhovna Rada of Ukraine, 24, 170 [in Ukrainian].

5. Kontseptsia reformuvannia mistsevogo samovriaduvannia ta terytorialnoi organizatsii vlady $v$ Ukraini zatverdzhena rozporiadzhenniam Kabinetu Ministriv Ukrainy vid 01.04.2014 r. № 333-r [The Concept of Reforming Local Self-Government and Territorial Structure of Power is approved by the resolution of the Cabinet of Ministers of Ukraine No. 333-r dated 01.04.2014]. (2014) Ofitsiynyi visnyk Ukrainy - Official Bulletin of Ukraine, 30, 831 [in Ukrainian].

6. Matvienko, A. (2011) reforma administratyvno-terytorialnogo ustroyu v Latvii [Reform of the administrative-territorial structure in Latvia]. Derzhava i pravo - State and Law, 54, 674-680 [in Ukrainian].

7. Metodyka formuvannia spromozhnykh terytorialnykh hromad, zatverdzhena Postanovoyu Kabinetu Ministriv Ukrainy vid 08.04.2015 r. № 214 [The Methodology of formation of capable territorial communities as approved by the Resolution of the Cabinet of Ministers of Ukraine No. 214 dated 08.04.2015] (2015). Ofitsiynyi visnyk Ukrainy - Official Bulletin of Ukraine, 33, 963 [in Ukrainian]. 
8. Skrypniuk, O. (2015) Detsentralizatsiya vlady yak chynnyk zabezpechennia stabilnosti konstytutsiynogo ladu: teoriia y praktyka [Decentralization of power as a factor in ensuring stability of the constitutional arrangement: theory and practice]. Viche: a civic, political and theoretical journal, 12, 22-24 [in Ukrainian].

9. Tkachuk, A. (2015) Latvia: dovga doroga reform. Robochi zapysky [Latvia: the long road of reforms. Working notes]. Kyiv: K.I.S. [in Ukrainian].

10. Obyednani hromady osvoily $95 \%$ subventsii na rozvytok infrastruktury svoikh terytoriy. Reforma diye! [Amalgamated communities used $95 \%$ of the subvention for development of infrastructure in their territories. The reform in action!] Retrieved from http: http://www.minregion.gov.ua [in Ukrainian].

11. History and progress of administrative-territorial reform in Latvia. (2009) Riga, Ministry of Regional Development and Local Government of the Republic of Latvia.

12. Chepel O. (2015) Combining of local communities in measures of decentralization in Ukraine. EUROPEAN JOURNAL of - LAW and PUBLIC ADMINISTRATION / Olga Chepel/ Ştefan cel Mare University from Suceava Faculty of Economics and Public Administration Department of Law and Public Administration, 2, 3, 37-43.

13. Tsurkanova, I. (2014) Demokraticheskiy politicheskiy protsess kak factor strukturnykh izmeneniy v sisteme ispolnitelnoy vlasti v sovremennoy Ukraine [The democratic political process as a factor of structural changes in the system of executive power of the present-day Ukraine]. Filosofia $i$ politologiia $v$ konteksti suchasnoii kultury - Philosophy and politology in the context of modern culture, 8, 273-276 [in Russian].

14. OTG: opryliudneno Kartu protsesu formuvannia obyednanykh hromad $\mathrm{V}$ Ukraini [Amalgamated Territorial Communities: the map of forming amalgamated communities in Ukraine has been presented]. Retrieved from http://decentralization.gov.ua/news [in Ukrainian]. 
15. Edvins Vanags \& Inga Vinks. Mestnoye samoupravlenie $v$ Latvii [Local self-government in Latvia]. Retrieved from https://cutt.ly/UQXDd3S [in Russian].

16. Zakon «Pro vnesennia zmin do deyakykh zakoniv Ukrainy shchodo vporiadkuvannia okremykh pytan organizatsii ta diialnosti organiv mistsevogo samovriaduvannia i rayonnykh derzhavnysk administratsiy» [The Law «On introduction of amendments to certain laws of Ukraine as regards adjustment of specific issues in organization and activity of local self-government bodies and district state administrations»)]. Retrieved from https://cutt.ly/nQXDgmA [in Ukrainian].

17. Reforma detsentralizatsii. Uriadovyi portal [The decentralization reform. The government portal]. Retrieved from https://cutt.ly/sQXDjW0 [in Ukrainian].

18. Pukis, M. (n.d.) Administratyvno-terytorialna reforma v Latvii [Administrative territorial reform in Latvia]. Retrieved from: https://cutt.ly/8QXDxUg [in Russian].

\section{АННОТАЦИЯ}

Статья освещуает особенности реформ децентрализации в Украине и Латвии, воплощуение их в жизнь и аспекты, которые являются определяюшими в реализации их успешного проведения: на латвийском примере для Украинь.

В публикации определено, что в Украине децентрализачия началась, как и в Латвии, с низового административно-территориального уровня и является глобальной перестройкой модели управления в государстве, создание эффективной системь территориальной организации власти в соответствии с положениями Европейской хартии местного самоуправления, но отсутствует действенный механизм, который бы обеспечил практическую реализацию права общины на прямые практические действия реализации ряда текущиих вопросов общества. 
А децеентрализаџчи в Латвии, так же, как и в Украине, все годы развития восстановленной независимости, включала несколько отдельных реформ, которые проходили не синхронно, из-за чего возникало много трудностей и проблем. Так, бюджетная децентрализачия предшествовала реформам советов и Админуустройству. Реформа местного самоуправления началась раньще и именно самоуправлению Закон дал больше полномочий, но общчинь не могли реализовать эти полномочия, были неукрупнены, небольшие по размерам и недостаточно способными действовать самостоятельно.

B cтатье определен ряд рекомендаџий, которые требуют их соблюдения при дальнейшей реформе децентрализачии в Украине: не откладывать меры по введению финансовой и административной автономии, иначе будет больие сопротивления, чем поддержки; способствовать не только объединением, но параллельно развивать и сотрудничество; по мере возможностей содействовать созданию и укрепнению единой ассоцииауии самоуправлений, проводя с ней консультации при каждом шаге реформ; консультироваться с каждым самоуправлением и компенсировать и помогать тем, кто может оказаться на окраине; децентрализировать отдельные функции вместе с реформами.

В исследовании сделаны выводы, что преодолевая долгий путь реформ в условиях нестабильности политической $u$ экономической, эффективность децентрализации в Украине зависит от того, насколько способны будут общины, которые объединились и насколько действенным инструментом с оказанию услуг населению они будут. Формирование общин в Украине сегодня происходит в условиях мировой пандемии, сложных геополитических трансформачий, экономического кризиса и требует как дальнейших исследований проблемь,, изучение зарубежного опьта, так и усилий всех без исключения: и законодателя, и руководителей общин, $и$ избранных, делегированньх от народа представителей ОТГ, $и$ от каждого рядового гражданина. 
Только сплоченная командная работа, направленная на положительный, четко определенный в стратегических изелях обшества, результат; добросовестная уплата налогов; прозрачное распределение и удачная реализация и освоение средств; жизнеспособна инвестиционная политика, - смогут гарантировать положительнылй результат и комфортную жизнь для населения в объединенной территориальной общине.

Ключевые слова: децеентрализаџия, Украина, Латвия, реформы, местное самоуправление, власть, объединенные территориальные общины.

\section{ABSTRACT}

This article highlights peculiarities of decentralization reforms in Ukraine and Latvia, their implementation and aspects which are crucial for their success, illustrating them with Latvian examples for Ukraine.

The publication states that just as in Latvia, the decentralization process in Ukraine began from the grassroot administrative-territorial level and strives for a global transformation of the country's administration model, and creation of an effective territorial structure of power in accordance with the provisions of the European Charter of Local Self-Government, but Ukraine lacks effective legal arrangements to ensure the people's right to direct practical action for solving current issues of their local community. Similarly to Ukraine, the process of decentralization in Latvia over the several decades of its restored independence included several stages of reforms that did not always run synchronously and caused a great deal of difficulties and problems. For instance, budget decentralization preceded the reforms of local councils and administrative structure. Reforms of local self-government began earlier, and the law gave more powers to local governments, but communities could not implement them as they were non-consolidated, small in size, and had little capability for independent activities. 
This piece of research sets forth a series of recommendations that are worth to be observed in the further course of the decentralization reform in Ukraine: do not postpone activities that introduce financial and administrative autonomy, otherwise the reform will see more resistance than support; promote amalgamation, but develop cooperation at the same time; whenever possible, encourage creation and strengthening of a united association of local governments, and consult it at every stage of reforms; consult with every local authority, compensate and help those who may find themselves on the margin; decentralize certain functions in the course of reformation.

The article suggests the following conclusions: proceeding on a long way of reformation in the conditions of economic and political instability, effectiveness of decentralization in Ukraine depends on how capable the united communities can become and how efficient they can be in providing all the necessary services to the people. Nowadays, communities in Ukraine are formed in conditions of the global pandemic, complicated geopolitical transformations, and an economic crisis, and this process requires further research in this field, a thorough study of international experience just as much as it requires certain efforts from virtually everyone: legislators, community leaders, people's elected representatives in communities, and each member of such community. Only a combination of teamwork meant to achieve a positive result of meeting the strategic goals of community, diligent payment of taxes, transparent distribution and successful allocation/use of funding, and a sound investment policy can guarantee the desired result and comfortable living for the people of an amalgamated territorial community.

Keywords: decentralization, Ukraine, Latvia, reforms, local self-government, power, amalgamated territorial communities. 